\title{
Long Distance Marriage Couple Communication Pattern during the Covid-19 Pandemic
}

\section{Pola Komunikasi Keluarga Pasangan Long Distance Marriage Saat Pandemi Covid-19}

\author{
Yani Tri Wijayanti ${ }^{1}$ \\ ${ }^{1}$ UIN Sunan Kalijaga Yogyakarta, Jl. Laksda Adisucipto, Sleman \\ *Corresponding author, e-mail: yani.wijayanti@uin-suka.ac.id
}

\begin{abstract}
The Covid-19 pandemic in Indonesia, made the government take steps to reduce the spread of the virus by making health protocols, restricting activities outsides the home, and the travel ban. This impact is strongly felt by long distance marriage (LDM) couples. LDM couples are committed by husband and wife who do not live together because of work demands. The communication is long distance using the media. The purpose of this study is to find out and analyze patterns of family communication in LDM couples during the Covid-19 pandemic. The method used is a case study, selection of research informants using purposive sampling techniques and data collection with in-depth interviews. Family communication patterns are formed from factors that influence, form of communication and quality of communication. When the Covid-19 pandemic intensity of family communication in LDM couples increased using media such as telephone, chat and video calls.
\end{abstract}

Keywords: Family communications patterns; Covid-19 pandemic; Long distance marriage

\begin{abstract}
Abstrak
Pandemi Covid-19 yang melanda Indonesia, membuat pemerintah mengambil langkah untuk mengurangi persebaran virus ini dengan membuat protokol kesehatan, membatasi aktivitas di luar rumah dan juga larangan untuk bepergian. Dampak ini sangat dirasakan oleh pasangan yang menjalani long distance marriage (LDM). Pasangan LDM dilatar belakangi oleh suami istri yang tidak tinggal bersama karena tuntutan pekerjaan. Komunikasi yang dilakukan adalah komunikasi jarak jauh dengan menggunakan media. Tujuan dari penelitian ini adalah mengetahui dan menganalisis pola komunikasi keluarga pada pasangan LDM saat pandemi Covid-19. Metode yang digunakan adalah studi kasus, pemilihan informan penelitian menggunakan teknik purposive sampling, dan pengumpulan data dengan melakukan wawancara mendalam. Pola komunikasi keluarga terbentuk dari faktor yang mempengaruhi, bentuk komunikasi serta kualitas komunikasi. Saat pandemi Covid-19 intensitas berkomunikasi keluarga pasangan LDM semakin meningkat dengan menggunakan media seperti telepon, chat, dan video calls.
\end{abstract}

Kata Kunci: Hubungan nikah jarak jauh; Pandemi Covid-19; Pola komunikasi keluarga 


\section{Introduction}

At the end of 2019, in Wuhan, China, a disease that is thought to have originated from animals emerged and infected humans and then spreads between humans. This disease is caused by a virus known as the coronavirus or novel coronavirus. Later, the World Health Organization (WHO) named the disease casue by the virus Covid with an additional 19, which refers to the year of its appearance. It is referred to as Covid-19. Although the Chinese government moved quickly to overcome and tried to contain its spread by closing down several affected cities, the spread was unstoppable and spread to all corners of the world. The situation was inseparable from the global human movement, which had not been restricted at that time, and the ease of the virus transmission from human to human. In early 2020, this virus has been found in more than 200 countries, including Indonesia. Indonesia officially announced the findings of its citizens who contracted the virus on March 2, 2020, directly by President Joko Widodo at the Presidential Palace (Ihsanuddin, 2020). Since this first case, the number of patient patients in Indonesia has been increasing every day, including the death rate it causes. As of April 24, 2020, there were 8,211 positive cases, with 1,002 recovered and 686 people dead (Herlina KD \& Hidayat, 2020). There are additional positive patients every day, and the virus continues to spread to areas in Indonesia.

The Indonesian government immediately moved to overcome the disease by compiling a number of protocols for handling it. This protocol was drafted by the Presidential Staff Office (KSP) and related ministries, especially the Ministry of Health. It was published by the Chief of Presidential Staff at the Press Conference on March 6, 2020. The protocols include Health Protocol, Border Monitoring Protocol, Educational Area Protocol, and Public Area and Transportation Protocol (Presidential Staff Office, 2020). The government also provides an official website, namely www.covid19.go.id, to provide various updates and information related to Covid-19.

One of the protocols that have been intensively socialized to the public is the health protocol. This protocol includes advice for anyone if they feel unwell by showing symptoms such as fever above 38 degrees Celsius, cough/runny nose, sore throat, respiratory problems, and immediately going to health services. To prevent and reduce the virus spread, people are also asked to maintain their health by washing their hands with soap correctly, using a mask when forced to leave the house, eating nutritious food, exercising, and so on. In addition, efforts to limit interactions are also resounded, namely by doing social or physical distancing.

This emphasis on "social/individual distancing" is implemented in various ways, such as dismissing schools and campuses, working from home regulation, not gathering or carrying out mass gatherings, preventing handshaking, not kissing, and so on. This effort is considered successful. At least, there has been a significant decrease in positive cases of Covid-19, ranging from 66-96\% each week (ECDC, 2020). Anderson, Heesterbeek, Klinkenberg, and Hollingsworth (2020) also said that individual behavior is fundamental in controlling the spread of Covid-19. Isolating oneself, getting medical information remotely except in severe conditions, and social distancing are the key. Wilder and Freedman (2020) agree that "social distancing" is designed to reduce interactions with the broader community. Individuals who have been infected but have not been identified can reduce the possibility of meeting each other. As this disease is transmitted from saliva splashes on people nearby, social distancing can reduce transmission. 
As the disease is transmitted with ease, President Joko Widodo asked all people to increase awareness of the spread of the coronavirus and the Covid-19. One way is to reduce activities outside the home, "it is time for us to work from home, learn from home, and worship at home" (Yahya, 2020). Unfortunately, even though there are rules for social or physical distancing, many people do not comply properly and even continue to have activities outside the home, even traveling outside the city, region, and even abroad. As a result, this virus continues to increase its spread in Indonesia.

At the same time, Muslims, including those in Indonesia, have also begun to face the holy month of Ramadan, which is followed by Eid Al-Fitr in 2020 (1441 H). There is a tradition in Indonesia during the fasting month, namely going out of the house to look for food and drink before breaking the fast (takjil) and praying tarawih prayers in mosques in a congregation, which causes many people to gather. Not to mention the tradition of going home before Eid al-Fitr, which causes people's movement in huge numbers. This, of course, adds to the likelihood of the virus spreading throughout the country. The government then decided to ban the homecoming activity, although some people considered the ban a little late because many residents had already done so. In addition, various activities are prohibited in several regions. Some cities classified as red zones, such as Jakarta, Bogor, Tangerang, and Bekasi, have issued large-scale activity restrictions or large-scale social restrictions (PSBB). DKI Jakarta, for example, began to enforce it on April 10, 2020, and then followed by several other areas such as West Java, Central Java, East Java and so on.

The prohibition of traveling out of town, returning to their hometowns, or going home is undoubtedly a problem for the community, especially for families whose spouses do not live together. So far, family visiting activities can be done regularly with time, which has become an agreement in the family. However, the prohibition of traveling outside the city or the region is an obstacle to meeting with family, spouse, children, and other relatives. If usually, they can come home once a month, once in two weeks, or even once a week to meet their family, now some have not been able to see their family for almost three months. The problem is that the time to meet the family is increasingly unclear because this pandemic's end is unknown. They do not know when to regroup during this kind of situation. Longing, worrying about each other's condition, wanting to tell a story directly becomes a problem faced by couples undergoing a longdistance marriage.

A family's ideal is to live and live together, so that husband and wife can jointly build an exemplary household commitment, and they can jointly care for children and see the child's growth and development firsthand. This conception applies as the family begins with a sacred bond that can unite two human beings is marriage, where marriage is essentially uniting two human beings, namely a man and a woman, to be able to live together to build a household. In marriage, there is a commitment, which of course involves an emotional bond between the two; there are responsibilities that must be shared; there are feelings involved.

Today we know that many married couples are forced to live separately and have to undergo long-distance marriages. According to Pistole in Ramadhini \& Hendriani (2015), the long-distance marriage describes the situation of a couple who are physically separated. One partner has to go to another place for a certain interest, while the other partner has to stay at home. They have to do a long-distance marriage (LDM) because of work where one of the partners must be in another city, another province or even in another country. Of course, when LDM couples are far apart, they need a 
stronger commitment to be able to maintain their household. A long-distance relationship is a challenge for them. They will encounter various obstacles, including not being able to communicate in person, inner needs not being met, and a sense of insufficiency when one partner is not always there, especially at critical times. Building a shared commitment certainly requires communication. Anita Vangelisti (2004), in her book Handbook of Family Communication, says communication is something that creates a family. When family members communicate, they do more than send messages to each other; they make connections. "Good family communication is crucial because it is the family we most often turn to for support.

Communication is an activity that must occur in a family. One member with another member can talk to each other, discuss, exchange ideas, etc. Communication between husband and wife, communication between father and child, communication between mother and child, communication between father, mother, and child, and communication between child and child must be built harmoniously and with good quality to form commitment and openness in the family. Every family's communication is ongoing with a unique history, present, and future (Segrin \& Flora, 2011). This implies that the communication process in the family is not only for the present, but what was done in the family in the past will be useful for the future. So, family communication that runs harmoniously can have a positive impact on the children in the future.

For example, AS, a wife who has been married to DW for ten years, experienced LDM throughout the ten years. AS Revealed that the most challenging thing when you are apart from your husband is when your child is sick, and your husband is still at work, which happens to be different from the island because he is bound by work commitments and cannot come home at any time. Of course, it is an obstacle for AS to take care of her sick child alone; they even have three relatively small children. Moreover, the husband is worried that the child's condition can only be monitored by communicating remotely and only can go home to meet the family once a month. Communicating with existing media such as telephone, video calls, whatsapp chat, becomes a medium that they use every day to continue to communicate both with their spouses and with their children. On the other hand, TS has another experience with his partner KF. Both are undergoing LDM for the last two years. TS has to work and is on a study assignment. Currently, they have not met for three months and only communicating with existing media. Even today, these couples do not know when to meet and be reunited.

Family communication itself is influenced by several factors. Devito in Novianti (2013) describes te factors as follows:

1. Self-image and Other's image. Self-image is defined as how individuals perceive themselves

2. Psychological atmosphere. It is an individual's emotional state, whether it is happy, sad, angry, etc., which can hinder or facilitate communication

3. Physical environment. Family is a physical environment that can affect the style and way of communicating

4. Leadership. There are three types of leadership in the family that can affect how to communicate, namely authoritarian, democracy and laissez fairez

5. Language. It is a tool to express something that is verbal

6. Age differences. It affects communication through choosing the right language. 
In conducting family communication, there are several forms of communication as conveyed by Djamarah (2004), the form of communication carried out, namely:

1. Verbal communication. It is a communication activity between individuals or groups that use language as a means of communication.

2. Nonverbal communication. In family communication, the non-verbal communication function will be felt if verbal communication cannot express something clearly. Non-verbal communication includes communication that can be conveyed in various ways, for example, by the movement of the body, facial expressions, eye gaze, appearance, and movement style. Non-verbal communication is beneficial and strengthens verbal communication (A Sari, Hubeis, Mangkuprawira, \& Saleh, 2010).

3. Individual communication/interpersonal communication. It is a type of communication that occurs in an interpersonal interaction; between husband and wife, between father and child, between mother and child, and between child and child.

4. Group communication. A close relationship between parents and children is significant to be developed in the family. This intimacy can be seen from the frequency of meetings between parents and children at one time or another.

Discussing family communication cannot be separated from the process of interpersonal communication. That is because in family communication there is communication involvement between father and mother, father and son, mother and child, and child and child. The quality of family communication, according to Devito (2011) can be seen from several things such as:

1. Openness (openness)

The quality of openness refers to at least three aspects; first, effective interpersonal communicators must be open to people with whom to interact, second, the communicator's willingness to react honestly to stimuli and the third is the "ownership" of feelings and thoughts, that the feelings and thoughts expressed are hers and he has to take responsibility

2. Empathy (empathy)

Henry Backrack (1976) in Devito (2011), defines empathy as a person's ability to 'know' what another person is experiencing at any given moment, from another person's point of view, through someone else's point of view

3. Supportiveness

There are principles in supporting family communication, namely being willing to provide opportunities for other family members so that other parties talk, listen actively to what the partner is talking about, teach children to listen, resolve conflicts early so that good communication is established (Gordon, 1991).

4. Positive attitude (positiveness)

According to Supratiknya (1995), if we think positively about ourselves, we will think positively about others. On the other hand, if we reject ourselves, then we will also reject others. The things we hide about ourselves are often things we do not like about other people. When we understand and accept our feelings, it is usually more comfortable to accept the same feelings that other people show. 
5. Equality (equality)

Communication can be said running effectively if there is a common understanding. It involves the members in solving particular problems. Furthermore, each member of the family has the right to contribute opinions.

Based on the factors that affect family communication, the form of communication in the family, and the quality of family communication, the author wants to discuss the communication patterns of the LDM couple during the Covid-19 pandemic. The pattern of communication is neither easy nor straightforward. The family is an institution consisting of a father, mother, and child. Family communication can be defined as a process of exchanging information or messages that involves family members, namely father, mother and child. In this process, there is a process of decreasing the value of family norms to children, and this is where there is an educational function. So it is not surprising that the family is the first and foremost educational institution known to children from birth. Moreover, the family is said to be a reference group, considered a behavior model in certain situations (Sejati, 2013).

According to Novianti (2013), family communication patterns describes family's tendency to build the most appropriate way to communicate with each other in it. The actual communication pattern refers to the mode that arises from a process that occurs in a family. Katz and Kahn (in Pace \& Faules, 2006) state that communication patterns indicate an identification to access communication behavior in a system because communication patterns provide context or space to understand specific behavior. The communication pattern is adjusted to the condition of the existing members when interacting with their environment. Family communication patterns illustrate the tendency of a family to develop how the most appropriate way to communicate with each other in it (Sanityastuti, Wijayanti, \& Kunandar, 2015).

Based on the explanation above, the authors focus this research on the communication patterns of married couples who are doing a long-distance marriage (LDM) and their experiences in communicating over long distances, especially in the Covid-19 pandemic situation, which causes unclear meetings and direct communication. This research focuses on knowing and analyzing the factors that influence family communication, the form of communication, and the quality of communication so that it can form family communication patterns.

\section{Method}

This study uses a case study research method. According to Cresswell (1998), the focus of a case study is the specification of a case in an event, whether it includes an individual, group, culture, or a portrait of life. A case study is an exploration of "a related system" or "a case or various cases" which from time to time through in-depth data collection and involving various sources of information that is "rich" in a context. This bound system is bound by time and place. Meanwhile, cases can be reviewed by a program, event, or an individual.

This research uses the case study method to reveal more deeply about the life of a married couple who should live together and live in one place, but must be separated by distance, space, and time and must communicate long distances. Yin (2013) said that case studies, in general, are a more suitable strategy when the central question of the research is related to "how" or "why" if the researcher has little opportunity to control the events to be investigated, and when the focus of the research lies on contemporary phenomena (present) in real life. So, the authors examine more deeply about the 
communication patterns carried out by the LDM partner, seen from the influencing factors, the communication form, and the communication quality.

The selection of informants is made using a purposive sampling technique, with the criteria being husband and wife couples who did LDM. There were ten informants in this study (5 married couples). The data collection technique was carried out using indepth interviews and observation. This study examines family communication with LDM couples with the following backgrounds:

Table 1. Informant Data (source: Author)

\begin{tabular}{ccccccc}
\hline No. & $\begin{array}{c}\text { Name } \\
\text { (Husband } \\
\text { and wife })\end{array}$ & $\begin{array}{c}\text { Age of } \\
\text { Married }\end{array}$ & $\begin{array}{c}\text { Time of } \\
\text { LDM }\end{array}$ & $\begin{array}{c}\text { Profession } \\
\text { (Husband and } \\
\text { wife) }\end{array}$ & $\begin{array}{c}\text { Number } \\
\text { of } \\
\text { children }\end{array}$ & LDM reason \\
\hline 1. & AG-LK & 8 years & 8 years & $\begin{array}{c}\text { Police-Civil } \\
\text { Servant }\end{array}$ & 1 & Profession \\
\hline 2. & YS-FG & 4 years & 7 months & $\begin{array}{c}\text { Civil Servant }- \\
\text { Housemaker }\end{array}$ & 2 & Profession \\
\hline 3. & DW-AS & 10 years & 10 years & $\begin{array}{c}\text { Private Employee- } \\
\text { Civil Servant }\end{array}$ & 3 & Profession \\
\hline 4. & NT-ZZ & $\begin{array}{c}13 \text { years } \\
\text { old }\end{array}$ & 5 years & $\begin{array}{c}\text { Civil Servant - } \\
\text { Housemaker }\end{array}$ & 3 & Profession \\
\hline 5. & TS-KF & 3 years & 2 years & $\begin{array}{c}\text { Lecturer- } \\
\text { Entrepreneur }\end{array}$ & 1 & $\begin{array}{c}\text { Work and } \\
\text { Study } \\
\text { Assignments }\end{array}$ \\
\hline
\end{tabular}

The analysis process in this study uses the component model analysis, including data reduction, data presentation, and drawing conclusions or verification. The activities can be carried out interactively with the data collection process as an interactive process, as suggested by Miles \& Huberman (Sutopo, 2006).

\section{Results and Discussion}

The LDM couples who have to communicate distantly in this study are motivated by work factors, where most of the husbands have to work outside the city or the province. This shows that the placement of work assignments (job demands) and meeting the needs of life (economic demands) are the main reasons for this couple to do LDM. Apart from work, there was one informant who was also apart from work due to study assignments. Because of his profession as a lecturer, TS does two reasons at once: work and study assignments. This is what keeps him away from his wife and children.

Maines (1993) in Margiani \& Ekayati (2013) explained that long-distance marriage is a physically separated husband and wife based on a commitment before marriage due to career or work demands. Based on Maines's opinion, of the five pairs of informants in this study, the main reason for doing LDM was because of the demands of one partner's job or career. In fact, of the five pairs of informants in this study, two pairs had committed LDM since the beginning of their marriage. AG and LK, a couple who have been married for eight years, undergo LDM the whole marriage age. Because AG happens to be a member of the National Police, he has to work in Lampung. His meeting time with family is usually once a week or every two weeks.

On the other hand, DW and AS have been married for ten years and have also been undergoing LDM for ten years. They have been blessed with three children. DW 
can only meet his family once a month because DW works as a private employee at a coal mining company in South Kalimantan.

Furthermore, NT and ZZ have been married for 13 years. Both have been undergoing LDM for the last five years due to the husband's career demands who got a promotion at a BUMN in Balikpapan, East Kalimantan. The husband had to stay away from his wife and three children who live in East Java.

Moreover, YS and FG also experienced the same thing. Their marriage had lasted for four years. They have been undergoing LDM because of the demands of the husband who was a civil servant in a ministry in West Java while the wife and child were in Palangkaraya, Central Kalimantan. They have only been LDM for the last seven months. Finallty, the last informants were TS and KF, who undergo LDM due to job demands and at the same time in working as a lecturer in West Java. TS had to complete further studies.

Work demands and study assignments are the reasons for these couples to do LDM. Rottel, et.al (Glotzer, 2007) stated that several factors cause long-distance marriage, such as financial needs (financial crisis), job mutations, or better opportunities to improve life. Of the three factors mentioned above, the couple tends to be in LDM due to economic factors. Informants undertake LDM because of economic considerations and get specific jobs or positions that require long-distance relationships. The LDM conducted by the informants was more about improving the quality of life, the quality of oneself to get a specific career path.

Duck and Gottman (Wood, 2010) conveyed "the lack of sharing of the little things in everyday life and the unreal expectations of spending time together to keep their lives intertwined, regular and ongoing conversations can form the basis of a relationship". Regular conversations are the basis of relationships in a family, where household harmony can also last because of good communication. Communication in the family can start from small things to the problems that the couple has to face to further form emotional bonds from family members. Factors that affect family communication include:

1. Self-image, where in the family each member can provide responses, opinions, views on other family members. Several informants said that when they were apart, communication with their spouses and children was always carried out routinely using the media of the telephone, chat on the WhatsApp application and video calls. In discussing daily activities, children are also given the opportunity to be able to tell about their daily activities. Nothing dominates.

2. Psychological atmosphere. Even though they are far from their names, humans have emotional states that can change. In this long-distance communication situation, emotions also become obstacles to communicating. For example, emotions can start from a misunderstanding so that one becomes angry. Of course, this becomes an obstacle when communicating. However, a psychological atmosphere can also be formed when, for example, making video calls, being able to see the partner's face directly. Of course, it can make communication more-smooth because you can see the condition of the partner, or the children are okay.

3. Physical environment. Father and mother are certainly the examples for their children. The style or way of communicating will also affect the communication style of the child. All informants conveyed that they always emphasized norms, politeness, and religious values in communicating. In this 
regard, couples also maintain the ethics of speaking between family members. Parents of children must be respectful, speak in a low tone, always say greetings at the beginning and end of the communication, and adjust to the customs of their respective regions. Here the family is a socialization system for children, where they experience a pattern of discipline and affective behavior (Sari, 2014).

4. Leadership. The husband or father as the head of the household certainly has a role as a leader, but when it comes to communicating, the style is mostly said to be a democratic style, where all family members can be involved in ongoing communication. No one is more authoritarian among family members.

5. Language. It is daily communication tool. The five couples of informants said that the language used daily is Indonesian, while some use the local language of the husband-wife couple, and some occasionally use English

6. Age Difference. There are frequently language problems because of the age difference between parents and children. Parents tend to use standard language, while children, because of social factors, use their age's social language. Based on information from the informants, it was stated that there were no language problems used by parents and children. They both used language that could be understood and understood by one another.

Long distance communication carried out by the LDM partner generally takes a certain amount of time to communicate freely without disturbing each other's activities or work. They have a mutual agreement on when is the right time to communicate because they cannot at any time to meet in person like other couples. The conditions of differences in distance and time in each region, busy work, working hours, of course, are factors that are considered by the LDM partner. Generally, this husband and wife communicate in the morning and at night. In the morning before doing activities and at night after returning home from work. This night is also used to communicate with the children. All informants use media such as telephone, chat via WhatsApp, and video calls.

The conversation is about the activities of each partner as well as the child's daily activities. If you cannot call in busy times, you can be using chat facilities, exchanging photos showing one another's activities, sending stickers, emoticons, or gifs as a form of communication with your partner. The use of communication media is a medicine to overcome feelings of nostalgia with spouses and children. During the Covid-19 pandemic, a heightened sense of concern shows that the intensity of communicating is getting more routine, to know each other's condition, to remind each other to maintain health, to eat regularly and to eat healthy food, to remind each other of existing health protocols. The prohibition on traveling between cities and regions makes the LDM couple want it or not to accept the existing situation,

Long distance communication conducted by the LDM pair using the media shows the forms of communication, namely:

1. Verbal communication. Communication is done by telephone, messages on whatsapp chat, and video calls. Verbal communication is felt to be more effective because messages can be immediately received well and provide feedback. With video calls, you can even see your partner's face directly. Couples who already have children, of course, want to be able to communicate with children every day, to see the child's growth and development, to find out 
about children's activities. The father can also show his role as a father, namely advising his children to be diligent in worshiping, studious, not being disobedient, and so on.

2. Nonverbal Communication. The form of non-verbal communication carried out by the LDM partner is the use of stickers, emoticons, and gifs. These symbols can represent feelings for one another. For example, a heart symbol, kiss emoticons, sad emoticons, and so on. Even when calling or video calls, nonverbal communication can be shown by facial expressions, whether you are in good health, sick, happy, sad, happy, or angry. It can also be known as the intonation of speech, the emphasis on certain words.

3. Individual communication. This communication takes place between husband and wife. In order to have a special time to discuss important things, they take advantage of the time to communicate when they are not with the children, for example, when in the office or at night when the child is asleep. Communication between father and child or mother and child can be done at any time, according to the times that have become routine for communication.

4. Group communication. Parents and children should not have any distance in the relationship. So communication in the family is important. As distance constraints, the group communication carried out by the LDM couple is by communicating via video calls, where parents and children can communicate simultaneously. However, when this couple gets together with their family, on average, they always spend special time together, such as eating together outside the home, doing family time by inviting children to play, shopping at the mall, and so on.

Doing long distance communication does not mean reducing the quality of the communication, with the existence of communication media makes it easier for LDM couples to communicate directly with their spouse or with children. The quality of this family communication is seen from:

1. Openness. In this aspect, the LDM partner always tries to be open and honest with the partner about what they feel and their respective thoughts so that trust is formed. Trust is the primary key because they are far away and can only communicate through the media. The informants conveyed to build trust by conducting more intensive communication to reduce the risk of miss understanding and miss communication, being honest with each other. Especially during the Covid-19 pandemic, the intensity of communication increased.

2. Empathy. By having a high sense of empathy between partners, it makes communication easier. Communication between partners, between parents and children, if based on empathy, can lead to a mutual understanding of each other's conditions. Due to the Covid-19 pandemic, some informants have been unable to meet their families for almost one month to three months, this condition makes mutual respect and understanding of each other even higher. Empathy can be defined as the ability to put oneself into situations and conditions faced by others, such as parents not demanding children more than the child's own abilities (Rahmawati \& Gazali, 2018).

3. Supportiveness. Several principles can be used in supporting family communication between parents and children. They are: a) being willing to allow other family members to talk, b) actively listening to what the partner is 
talking about, c) teaching children to listen, and d) resolving conflicts early so that communication runs well (Gordon, 1991). In this aspect of mutual support, the LDM couple does this by communicating via video calls to provide the opportunity to communicate directly. The father allows the child to tell about the child's daily activities. The husband/father also provides support and attention to what the children and wife have done. Husbands allow their wives to submit complaints or problems they are facing, and they try to be able to immediately solve the problem without having to wait for it to drag on. During the Covid-19 pandemic, they shared information regarding their respective conditions, encouraged each other to be patient, and reminded each other to maintain health.

4. Positiveness. In this aspect, the LDM partner implements positive thinking with their partners. With honesty and trust, they always think positively even though they cannot always meet face to face, and they must be separated by time and distance. With positive thinking, this can reduce worrisome about the partner's condition.

5. Equality. There are similarity and equality of understanding in communicating. By using the same language, family can reduce the occurrence of misunderstandings. In communicating, all family members have the same opportunity to talk. There are intimacy and closeness so that no one dominates and household harmony can be adequately maintained. In the decision-making process, the husband or wife has the same opportunity to provide opinions so that a good and mutually agreed decision can be obtained.

Communicating remotely for an extended period results in not meeting and communicating directly. Thus, the interactions carried out using more communication media. Based on the experience of communicating remotely among LDM partners, especially amid the Covid-19 pandemic, communication patterns can be obtained based on factors that affect family communication, the form of communication, and the quality of family communication. This pattern is illustrated in the following image: 


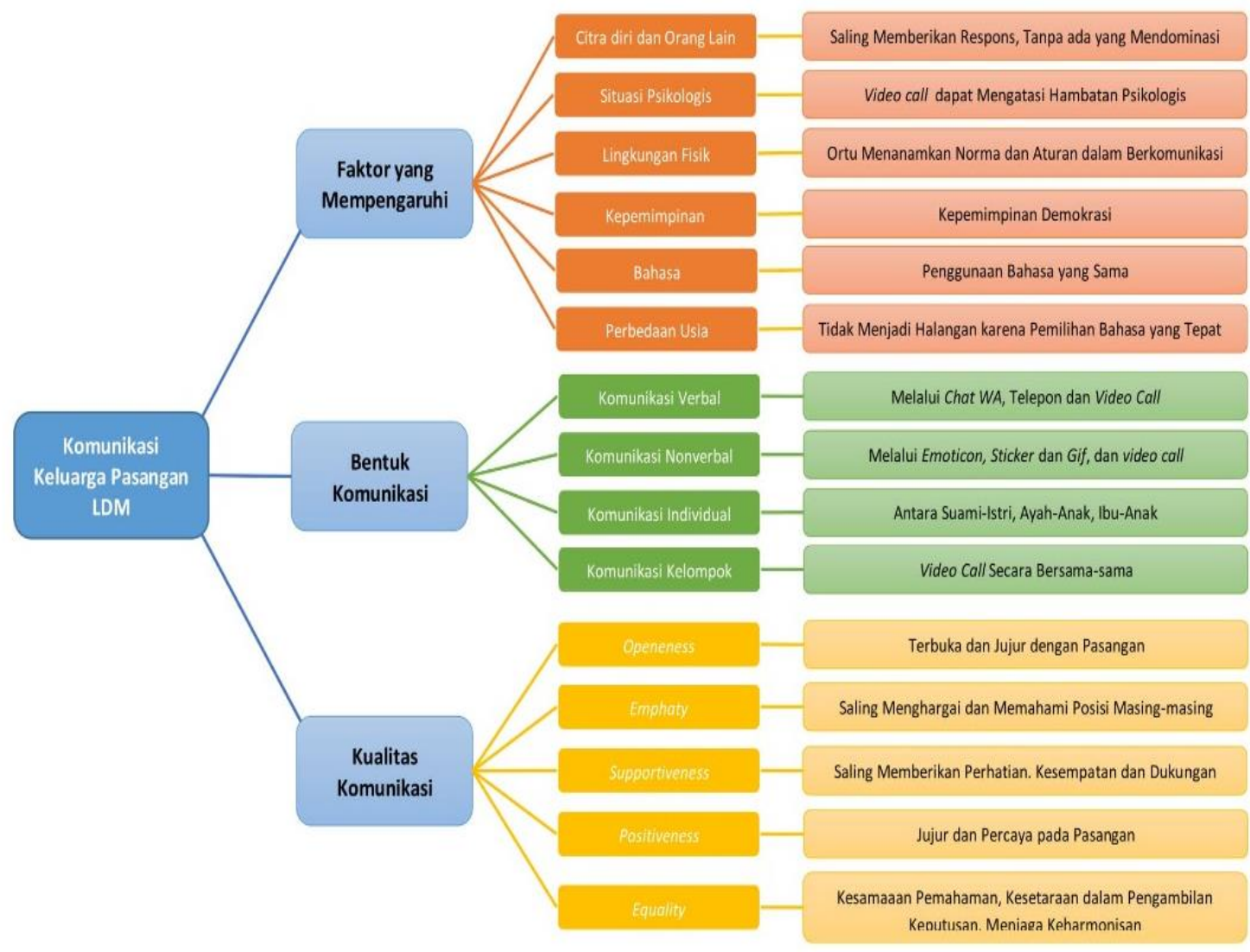

Figure 1. Family Communication Patterns in Long Distance Marriage Couples During the Covid-19 Pandemic (source: Author)

This communication pattern can be understood as a way to convey messages or information used by one person to another. In the context of family communication, communication patterns are carried out by continuous communication and become a habit of the LDM partner. During this pandemic, the intensity of communication has increased. Couples express their thoughts, feelings, and reactions to each other's current situations or by showing mutual acceptance, understanding, support, and mutual cooperation.

\section{Conclusion}

The primary reason a couple chooses to undergo Long-distance Margiage (LDM) is due more to the factor of job demands and fulfillment of life necessities, so it requires one of the partners to live and work outside the region or the city. To be able to maintain household harmony is to communicate continuously using existing communication media. Communication is a decisive factor in the family because couples need to communicate to find out each partner's feelings and conditions, create hope, and maintain commitment. Their communication patterns are based on three aspects: the factors that affect family communication, the form of family communication carried out, and the effectiveness of communication as seen from the quality of family communication.

The factors that influence this are shown by providing mutual responses, concern for one another, and no domination. Psychological barriers can be overcome by communicating with video calls. In communicating, parents instill rules and norms that apply in the family, using the same language, namely Indonesian and the respective 
regional languages. There are no obstacles due to age differences between parents and children because it can be overcome by choosing the right language when communicating.

Based on the communication experience of the LDM partner, the forms of communication carried out include verbal, non-verbal, individual, and group communication. Verbal communication is done by telephone, WhatsApp chat, and video calls. Non-verbal communication is done by sending stickers, emoticons, and gifs to each other, and being able to see facial expressions directly can be seen during video calls. Individual communication in family communication includes father-mother, father-child, and mother-child communication. To be able to do group communication in family communication, the LDM couple uses the media of video calls so that they can simultaneously communicate together.

For the quality of family communication that has been carried out by the LDM couple, some factors are required, including openness, honesty with partners, mutual respect and understanding of each other's position, giving mutual attention, opportunity, and support to one another, trust in partners, and a shared understanding, equality in decision-making, as well as maintaining household harmony together. During the Covid-19 pandemic, the intensity of communication, attention, and support for one another has increased. Based on the research that has been done, some suggestions can help LDM couples communicate and maintain household harmony. It is by always increasing the frequency and intensity of communication and increasing the acceptance of and support for each other, not only during a pandemic like this.

\section{Acknowledgements}

The author would like to thank the research informants and various parties who have helped the author when conducting research and completing the writing of this article. Hopefully, the results of this research can be useful for readers.

\section{References}

Anderson, R. M., Heesterbeek, H., Klinkenberg, D., \& Hollingsworth, T. D. (2020). How will country-based mitigation measures influence the course of the COVID19 epidemic? The Lancet, 395(10228), 931-934. https://doi.org/10.1016/S01406736(20)30567-5

Cresswell, J. W. (1998). Qualitative Inquiry and Research Desain Choosing among Five Traditions. The United State of America: Sage Publication. Inc.

Devito, J. A. (2011). Komunikasi Antar Manusia Edisi Kelima. Jakarta: Kharisma Publishing.

Djamarah, S. B. (2004). Pola Komunikasi Orang Tua \& Anak dalam Keluarga. Sebuah Perspektif Pendidikan Islam. Jakarta: Rineka Cipta.

ECDC. (2020). Coronavirus disease 2019 (COVID-19) pandemic: increased transmission in the EU/EEA and the UK - sixth update. ECDC.

Glotzer, R. (2007). Miles That Bind: Commuter Marriage and Family Strengths. Michigan Family Review, 12, 7-31. https://doi.org/10.3998/mfr.4919087.0012.102

Gordon, T. (1991). Menjadi Orang Tua Efektif: Petunjuk Terbaru Mendidik Anak yang Bertanggung Jawab, Terjemahan: Farida Lestira. Jakarta: Gramedia Pustaka Utama.

Herlina KD, \& Hidayat, K. (2020). Update Corona Indonesia, 24 April 8.211 Kasus 
Positif, 1.002 Sembuh, 689 Meninggal. Retrieved from Nasional Kontan website: https://nasional.kontan.co.id

Ihsanuddin. (2020). Fakta Lengkap Kasus Pertama Virus Corona di Indonesia. Retrieved from Nasional Kompas website: https://nasional.kompas.com

Kantor Staf Presiden. (2020). Penanganan covid-19 protokol kesehatan. Retrieved from Kantor Staf Presiden website: http://ksp.go.id/wpcontent/uploads/2020/03/Protokol-Kesehatan-COVID-19.pdf

Margiani, K., \& Ekayati, I. . (2013). Stres, Dukungan Keluarga Dan Agresivitas Pada Istri Yang Menjalani Pernikahan Jarak Jauh. Persona:Jurnal Psikologi Indonesia, 2(3), 191-198. https://doi.org/10.30996/persona.v2i3.134

Novianti, E. (2013). Pola Komunikasi Keluarga Antar Budaya. Bandung: Arsad Press.

Pace, R. W., \& Faules, D. F. (2006). Komunikasi Organisasi. Strategi Meningkatkan Kinerja Perusahaan. Bandung: Remaja Rosdakarya.

Rahmawati, \& Gazali, M. (2018). Pola Komunikasi Keluarga. Al-Munzir, 11(2), 163181.

Ramadhini, S., \& Hendriani, W. (2015). Gambaran Trust pada Wanita Dewasa Awal yang Sedang Menjalani Long Distance Marriage. Jurnal Psikologi Klinis Dan Kesehatan Mental, 4(1), 13-14. https://doi.org/10.1002/ejoc.201200111

Sanityastuti, M. S., Wijayanti, Y. T., \& Kunandar, A. (2015). Pola Komunikasi Keluarga dalam Membangun Akhlakul Karimah. CHANNEL Jurnal Komunikasi, 3(2), 113-122. https://doi.org/10.12928/channel.v3i2.3278

Sari, A, Hubeis, A., Mangkuprawira, S., \& Saleh, A. (2010). Pengaruh Pola Komunikasi Keluarga Dalam Fungsi Sosialisasi Keluarga Terhadap Perkembangan Anak. Jurnal Komunikasi Pembangunan, 8(2), 36-45. https://doi.org/10.29244/jurnalkmp.8.2.

Sari, Afrina. (2014). Komunikasi dan Pola Asuh Anak Balita - Remaja dalam Keluarga Betawi Jakarta dan Bekasi. Jurnal ASPIKOM, 2(2), 63-73. https://doi.org/10.24329/aspikom.v2i2.60

Segrin, C., \& Flora, J. (2011). Family Communication (2nd ed.). New York: Taylor \& Francis.

Sejati, V. A. (2013). Pendekatan Komunikasi Keluarga di Kabupaten Magetan untuk Mencegah Dampak Negatif Media Sosial bagi Anak di Bawah Umur. Jurnal ASPIKOM, 2(1), 619-628. https://doi.org/10.24329/aspikom.v2i1.40

Smith, A. W., \& Freedman, D. O. (2020). Isolation, quarantine, social distancing and community containment: Pivotal role for old-style public health measures in the novel coronavirus (2019-nCoV) outbreak. Journal of Travel Medicine, 27(2). https://doi.org/10.1093/jtm/taaa020

Supratiknya, A. (1995). Komunikasi Antar Pribadi. Yogyakarta: Kanisius.

Sutopo, H. B. (2006). Metode Penelitian Kualitatif. Surakarta: UNS Press.

Vangelisti, A. L. (2004). Handbook of Family Communication. New Jersey: Laurence Erlbaum Associates Publishers.

Wood, J. T. (2010). Interpersonal Communication: Everyday Encounters. Boston: Wardsworth.

Yahya, A. N. (2020). Pemerintah Diminta Terbitkan Aturan soal Social Distancing. Retrieved from Nasional Kompas website: https://nasional.kompas.com

Yin, R. K. (2013). Studi Kasus : Desain dan Metode. Jakarta: Raja Grafindo Persada. 